\title{
Peculiarities of Implementation Export Credit Agency in Ukraine: Investment Aspects
}

\author{
Kornieieva Iuliia \\ Department of Macroeconomic Regulation \& International Economic Relations, Academy of Financial Management, Kyiv, Ukraine
}

Email address:

korneevaj@ukr.net

\section{To cite this article:}

Kornieieva Iuliia. Peculiarities of Implementation Export Credit Agency in Ukraine: Investment Aspects. International and Public Affairs. Vol. 2, No. 1, 2018, pp. 28-38. doi: 10.11648/j.ipa.20180201.14

Received: March 5, 2018; Accepted: April 2, 2018; Published: May 9, 2018

\begin{abstract}
This study examines the role of the ECA as an important element in the system of attracting investment resources. The functioning of the ECA is seen as an institutional stimulus for improving investment climate, promoting export, increasing the competitiveness of the national economy and developing export potential in both the private and public sectors. The author examines the opportunities that ECA creates in financing capital investment, which is especially important for state-owned companies in Ukraine. The author emphasizes the importance of ECA in creating conditions for attracting financial resources on favourable terms for state corporations which seek to purchase foreign expensive equipment, that do not have analogues on the domestic market. Major objective of this study is to develop recommendations concerning creation prerequisites for practical implementation of ECA in Ukraine. The author proposed new financial instruments which with support from international donors will contribute to the effective activity of ECA in Ukraine. These include the instrument of the provision of guarantees to the national ECA for the entry into international capital markets - ECA's emission guarantees; guarantees of support of ECA'S projects that will facilitate the cooperation with foreign financial institutions; as well as financial instruments that will perform the compensatory function of equalizing market interest rates for large projects and for long periods of time. The importance of establishing the register of Ukrainian state-owned enterprises which will be included into the ECA`s program in cooperation with IMF, WB, EBRD and other IFOs is emphasized.
\end{abstract}

Keywords: Export Credit Agency, International Financial Organization, ECA's Emission Guarantee, Guarantee for Support of ECA`s Projects, Investment

\section{Introduction}

The development of the institutional environment is an important element in attracting investment into the country. The lack of a complete system of investment insurance reduces the competitiveness of national companies in foreign markets. Such disadvantages can be effectively neutralized by the introduction of the Export Credit and Investment Insurance Agency. During the last financial crisis, the lack of financial resources on the credit and insurance markets has reinstated interest in financing options offered by the Export Credit Agencies (ECAs). In 2014, ECA provided support for export and investment agreements totalling more than 119.33 billion U.S. dollars. Due to the unfavourable situation in capital markets, this indicator dropped by $29 \%$ to 84.63 billion U.S. dollars in 2015. However, in 2016, the volume of financial support has almost doubled in comparison with the previous year and has reached the mark of 124.9 billion U.S. dollars [1].

In 2011, the Government of Ukraine developed a draft Law of Ukraine № 9373 "On State Financial Support of Export Activities". The Verkhovna Rada of Ukraine adopted the document in May 2012, but the Law did not come into force, since it was vetoed by the president. On December 20, 2016, the Law of Ukraine № 1792-VIII “On Providing for Large-Scale Export Expansion of Goods (Works, Services) Originating in Ukraine through Insurance, Guarantees and Cheapening of Export Credits" was adopted [2]. An important decision regarding creation of ECA in Ukraine within six months from the date of the adoption of the Law was taken. The authority developed special Plan for the preparation of draft acts necessary to ensure the implementation of this Law, which clearly outlines the algorithm for the establishment of a relevant institution in Ukraine. But The Ministry of Economic Development and 
Trade (MEDT) failed to agree on a draft document about the procedure of introducing ECA in Ukraine with the Ministry of Finance, The Ministry of Justice and State Fiscal Service (SFS), and to approve the final resolution with the Cabinet of Ministry of Ukraine (CMU) until June 15, 2017. The MEDT of Ukraine has appealed to the government to provide ECA with budget financing at the level of 345 million UAH in 2018. However, according to the Law of Ukraine № 2246VIII of 07.12.2017 "On the State Budget of Ukraine for 2018 " the state budget foresees funding only 200 million UAH in 2018 for the formation of the authorized capital of the public joint-stock company "Export-credit agency"; also 50 million UAH is provided for the functioning of the institution support and promotion of exports [3]. The disadvantage of the Law № 1792-VIII is a condition that allows ECA to provide loans or guarantees to enterprises from the state budget, which contradicts the Consensus of Organisation for Economic Co-operation and Development (OECD) concerning basic principles of ECA`s activity. According to this the model of Ukrainian Export Credit Agency is discussed with the International Monetary Fund (IMF) in the context of solving the problems of managing potential fiscal risks that could create ECA. The latest version of the memorandum with the IMF confirmed the intention of Ukrainian authority to postpone the creation of ECA in Ukraine for three years; this at the same time contradicts adopted in 2016 legislation [4]. Despite the adopted in 2016 legislation, the creation of ECA in Ukraine is still at an early stage.

The study of the best international practice of implementation specialized institutions that promote investment and capital inflows as a result of the expansion of enterprises into foreign markets will help to develop an optimal mechanism for the introduction of relevant market institutional units for Ukraine, taking into account the peculiarities of the national economic system.

\section{Literature Review}

Nobel Laureate of 2001 Joseph Stiglitz describing the general principles of foreign trade explained how selective state interference could improve the functioning of the market mechanism. According to Stiglitz the main cause of market imperfections is the existence of structural problems such as information asymmetry, which can be overcome by state, and thus improve the market failure [5, 6]. Nobel Laureate of 2008 Paul Krugman, devotes much attention to the study of the problems of international trade development under globalization processes; the scientist analyses the impact of trade liberalization on various spheres of the economy. His theory of modern international trade points to the causes of the domination of industrially developed countries [7-10]. In «Geography and Trade» published in 1991, Krugman explains that, poor countries remain on the periphery of trade flows as a result of the geographical concentration of industry [11]. Scientist defends Keynesian views concerning state intervention to economy. Krugman notes that the regulatory system should be based on the combination of the role of the state and free markets, while at the same time denying blind intervention in economic processes. Krugman's "Positive theory" envisages the creation of such conditions that promote the development of the enterprise, industry, region, etc., but, as the author points out, these are not ideal conditions, but only incentives. P. Krugman wrote that globalization intensifying the concentration of capital, promotes the creation of financial centers and their growth [12]. In the context of this statement the competing for capital and for a place in global trade flows for transition economies and emerging markets is rather difficult.

Based on the above, it is important to provide incentives for economic development and growth in the form of specialized institutional units. Introduction of an Export Credit Agency is fully consistent with Krugman's concept of creation of incentives that will enable the state to support exports and stimulate investment in capital assets by marketbased methods. Also the concept of ECA is fully consistent with the ideas of Stiglitz regarding the leading role of the state in overcoming information asymmetry.

Another important issue along with information asymmetry is the insufficient level of available resources that can be directed to financing of trade and investment in capital assets for countries that aspire to sustainable economic growth. The conditions for rationing loans are described in J. Stiglitz and E. Weiss "Credit rationing in markets with imperfect information". This research is devoted to the development of a model of the credit market in the context of rationing loans, when banks reject loan applications due to the existence of excessive demand and lack of financial resources [13]. Implementation of specialized institutions that will promote simplification of attracting financial resources, both domestically and on the international capital markets will facilitate the solution to this problem.

Problems concerning the development of export potential and stimulation of investment in capital assets have always attracted the attention of leading world economists. M. Mazzucato and G. Semieniuk noted the role of government in the financing of innovative projects, stressing that government agency can take to insure risks that private capital will refuse to take, thereby encouraging investment in innovation and long-term development of the country [14]. A. Goldzimer investigated the growing influence of Export Credit Agencies on international finance, defining them as drivers of globalization, and noting the growing role of insurance services for export credits and investment contracts [15]. T. Ehlers studying the possibility of financing infrastructure projects from both private and public sources, emphasized the importance of using a variety of financial instruments, which would increase the investment attractiveness of infrastructure objects for a wide group of investors and create opportunities for better risk diversification. The author notes the important role of Export Credit Agencies in this direction [16]. R. Bhandari and C. Maurer focused on defining the role of public finances in 
Sustainable Development Policy Support, analysing the possibilities of financing the climate programs from public and private sources. The authors emphasize that over time the role of Export Credit Agencies in these projects will significantly increase [17].

Traditionally, the ECA is considered in terms of export promotion, but the scientific literature does not pay enough attention to the investment aspects of the work of these institutions. In the context of this research an emphasis will be made on potential opportunities that ECA create in terms of promotion of investment activity with accents on Ukrainian realities.

\section{Discussions}

\subsection{Basic Principles of ECA `s Activity: Investment Aspects}

Export-import operations, inflows of investments into the country affect the balance of payments, determine the direction of monetary policy, affect the sustainability of public finances, in particular, in terms of the development of debt policy and in the context of fiscal risk formation; also have a significant impact on determining the main directions of the state investment strategy. The functioning of Export Credit Agencies in this case should be considered as an important element in the system of attracting investment resources and improving the investment climate in the country, in terms of promoting exports, increasing the competitiveness of the national economy and developing export potential in both the private and public sectors. Organizational, institutional and other forms of promoting export activity and attracting investment, in particular the incentives for capital investments, that have a significant impact on the national economy and public finance, are the task of national regulators.

The main purpose of creating Export Credit Agency is to increase the competitiveness of domestic exporters and stimulate capital investment, which have positive impact on economic growth due to the diversification of the economy. Financial instruments of ECA designed to protect exporters from losses related to various types of risks that impede their participation in foreign trade. In terms of reducing information asymmetry ECA provides organizational, informational and analytical support for export and investment operations. Agencies actively assist in processes of internationalization of the domestic companies' activities and their expansion into foreign markets. ECA`s guarantees are used to finance the import of equipment, machinery, process lines, mini-factories and related engineering services, etc.; construction projects with participation of foreign general contractors; import of intellectual property rights; import of research and development; capital expenditures on investment projects carried out by companies with foreign participation, etc. Traditionally, Export Credit Agencies provide the following services: export credit insurance, export loan guarantee, overseas investment insurance, direct loans, and interest rate subsidies. ECA guarantees or insures long-term investment loans for the financing capital investments, typically provided by national private or public banks (in some cases foreign) on contracts for the purchase of foreign goods and services by national companies. Financing under the guarantee of national export agencies is one of the cheapest types of financing available for a prolonged period (usually five to ten years).

Figure 1 shows the mechanism of overseas investment insurance with the support of the ECA.

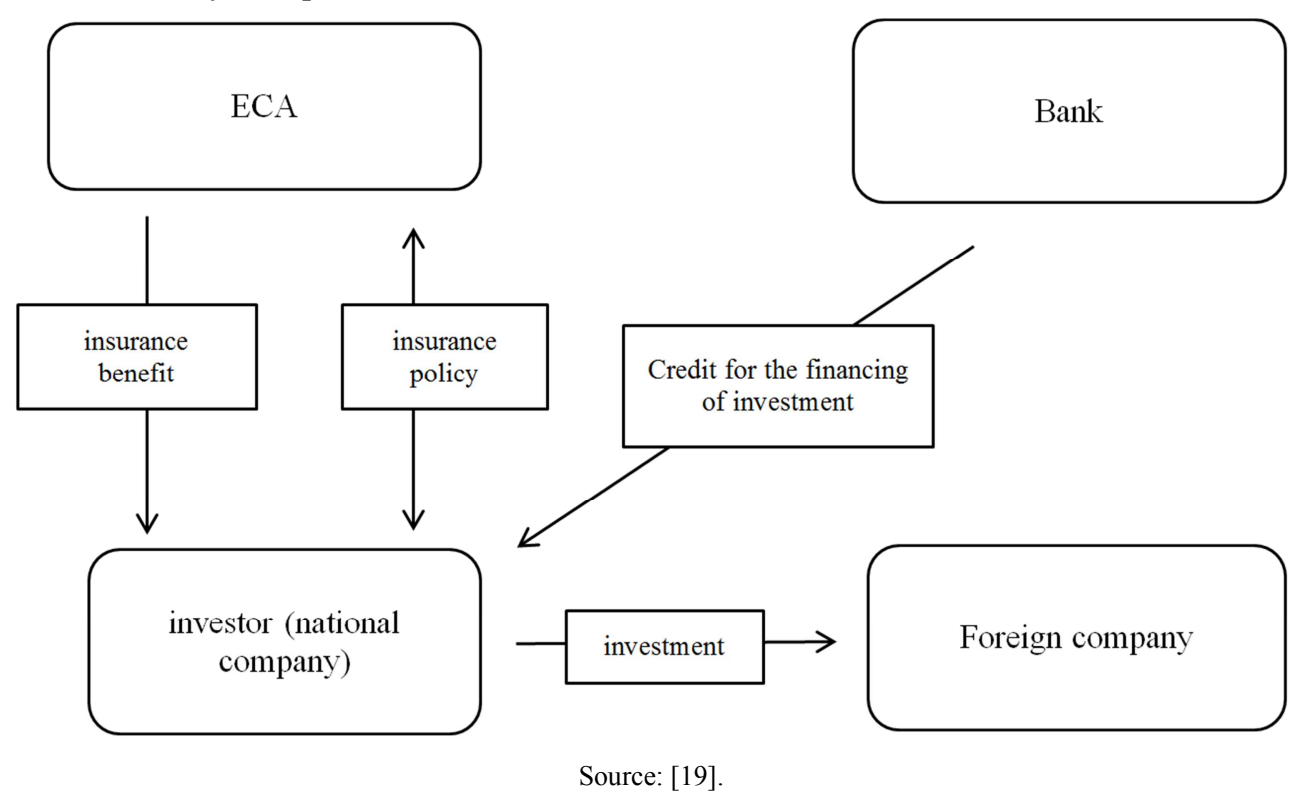

Figure 1. Mechanism of overseas investment insurance.

However, the insurance contract can be signed directly with the bank, which acts as a creditor under an investment contract. This mechanism is different from the mechanism of overseas investment insurance and shown in Figure 2. 


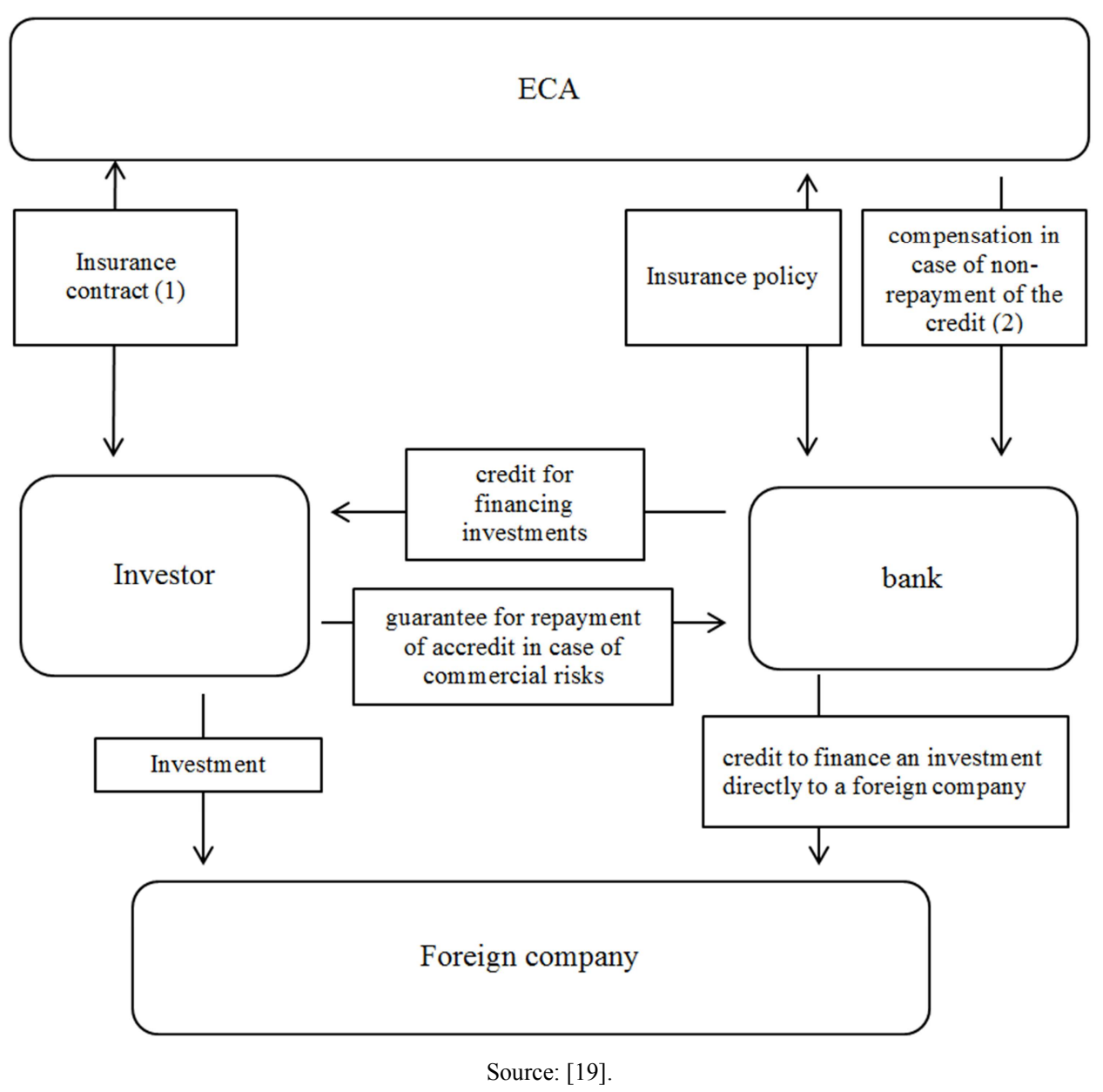

Figure 2. Mechanism of Insurance of Credit for the Financing of Investment in Foreign Countrie.

(1) The condition of insurance is also the partial financing the investment from the own financial sources of investor acccording to the agreement between ECA, bank and investor (usually at least $25 \%$ ) [19].

(2) Insured event occurs due to commercial (incapacity or rejection of the debtor to pay) or territorial reasons (impossibility of conversion and / or transfer of revenues, expropriation, political violent actions and breach of contractual obligations) [19].

To create favourable prerequisites for company`s growth it should be taken into account the mechanisms that creates ECA in terms of attracting financial resources. Considering the weak capacity of financing large investment projects from state budget, Ukrainian state-owned companies (SOEs) shouldn't miss the opportunity to use such benefits. Investments in the development of export potential in the public sector create long-term prerequisites for reducing fiscal risks. Analysing the indirect impact of Export Credit Agencies on reducing fiscal risks for the state budget, it should be noted that the use of financial instruments of ECA contributes to improving the competitiveness of state-owned enterprises. The cooperation of state-owned companies with these institutions contributes to the development of their export potential, the growth of profitability due to the attraction of investment resources, which in the medium-term will contribute to reducing the direct fiscal risks created by SOEs for the budget. Obtaining financing on favourable terms will improve the position of the importer, expanding opportunities for capital investment. If an importer is a state corporation that needs to purchase foreign equipment, machinery, vehicles not represented on the domestic market, the question of attracting necessary for the implementation of this project financing without creating additional budgetary burden is arises. In this case, the prospects of obtaining foreign ECA`s guarantees open the possibility for a SOEs to receive funds for capital investment in a foreign market at a low interest rate, which is especially relevant for Ukrainian realities. The import financing mechanism under the ECA`s guarantees can reduce the cost of financing compared to classic lending, due to the possibility of obtaining financing from a foreign bank, where interest rates are lower compared to Ukrainian ones. Due to the cooperation with ECA importing company gets the opportunity of repaying part of the debt from the funds generated by investment project implementation. For the Ukrainian company there is an opportunity to receive a large long-term loan from a foreign bank at a favourable interest rate. Figure 3 shows the import financing mechanism under the ECA's guarantee, which clearly reflects the potential benefits for both sides of the export-import agreement. 


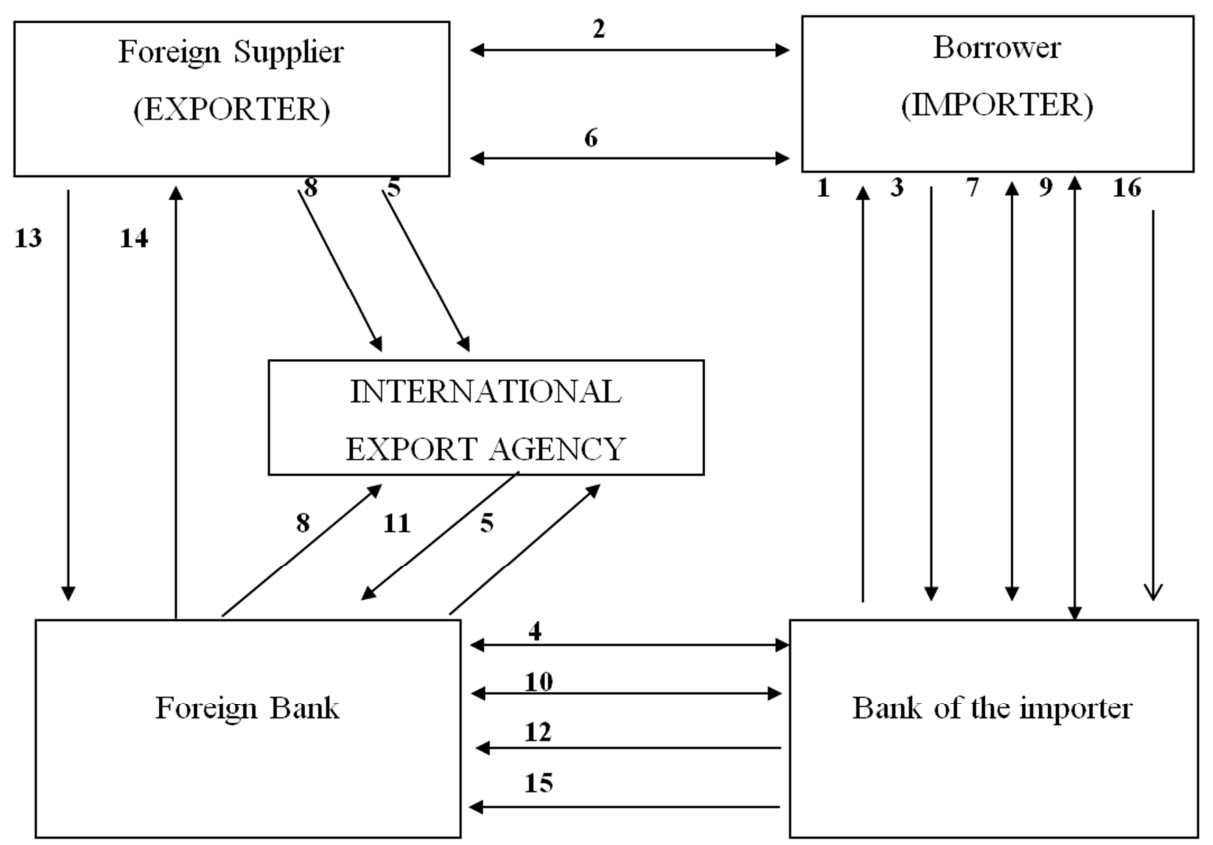

Source: compiled by the author.

Figure 3. Scheme for obtaining import financing under the product "Long-term import financing under ECA 'sguarantees".

1. the bank carries out a preliminary analysis of the borrower on the state of his compliance with the principles and conditions of lending accepted by the bank;

2. the exporter and importer agree on the terms of delivery of goods or services;

3. the borrower applies for the bank;

4. the foreign bank and the bank of the importer agree on the terms of financing under the Framework Credit Agreement (if necessary, sign the agreement between the bank of importer and foreign bank that governs the general terms of the lending, including the lending limits);

5. the supplier / foreign bank sends an application to ECA and obtains prior approval for the provision of insurance coverage;

6. the exporter and importer sign a contract for the supply of goods and services;

7. the borrower and the bank agree on its financial conditions;

8. the exporter and the foreign bank finally agree on receipt of the insurance export cover of the ECA;

9. the bank of importer and the borrower conclude a loan agreement, a letter of credit agreement, a security agreement (maintenance should include the fulfilment of obligations arising from loan agreement and from the contract of uncovered letter of credit);

10.the bank of importer and the foreign bank sign Individual Credit Agreement which regulates the receipt of credit funds to finance the relevant import contract of the client within the Framework Credit Agreement;

11.the international ECA provides insurance coverage;

12.the bank of the importer issues a letter of credit through a foreign bank in favour of the exporter;

13. the supplier provides the documents specified on the letter of credit;

14. foreign bank verifies the documents, makes a payment on the letter of credit in favour of the exporter at the expense of the credit line, opened by the importing bank;

15. the loan is repaid by the bank of importer in accordance with the conditions of the Individual Credit Agreement;

16.the importer-borrower repays the debt in accordance with the terms of the loan agreement of his bank.

Still there exists the barrier for effective cooperation with foreign ECA for companies in Ukraine. According to the latest data (26 January 2018) of OECD Country Risk Classifications of the Participants to the Arrangement on Officially Supported Export Credits, Ukraine is in the 7th group among countries with the highest risk, the same as Guinea, Bosnia and Herzegovina, Venezuela and Iraq; for comparison, Honduras and Vietnam belong to the 5 category of risk [18]. This fact makes this method of attracting capital more expensive because the ECA's Commission for risk increases with the passing to a lower group.

For example, the Czech Export Credit Agency EGAP provides its services for Insurance of Investment of Czech Legal Persons in Ukraine, taking into account the following commissions: Standard self-retention in covering commercial risks $10.0 \%$; Standard self-retention in covering political risks $10.0 \%$; and Insurance premium ranges from $1.17 \%$ p.a. credit principal in case of arranged International Investment Protection and Promotion Agreement and 1.56\% if not arranged. For countries of 0 risk category, premium rate results from the actual market assessment of a similar type of risk [19]. Nevertheless, the cooperation with foreign ECAs can be beneficial and perspective for Ukraine. 


\subsection{Best world's Export Credit Agencies Practice}

Table 1. ECA: ownership, regulatory system, cooperation with financial institutions.

\begin{tabular}{|c|c|c|c|c|}
\hline ECA/Country & Year & Ownership & Cooperation with financial institutions & Regulatory system \\
\hline $\begin{array}{l}\text { Export Development } \\
\text { Canada / } \\
\text { Canada }\end{array}$ & 1944 & $100 \%$ state property & $\begin{array}{l}\text { the Business Development Bank of } \\
\text { Canada, BDC }\end{array}$ & $\begin{array}{l}\text { OECD Consensus, Export Development } \\
\text { Act } 1969 \text { (Chapter 10) }\end{array}$ \\
\hline $\begin{array}{l}\text { Hungarian Export Credit } \\
\text { Insurance Pte Ltd. } \\
\text { (MEHIB) / Hungary }\end{array}$ & 1994 & $\begin{array}{l}100 \% \\
\text { state property }\end{array}$ & $\begin{array}{l}\text { Hungarian Export-Import Bank plc } \\
\text { (EXIM), The European Investment Bank } \\
\text { (EIB), Export Import Bank of China, } \\
\text { IFC, EBRD, Eximbank Romania, } \\
\text { Vnyesekonombank }\end{array}$ & $\begin{array}{l}\text { OECD Consensus, Berne Union, } \\
\text { EU directives [20-22], Act } \\
\text { CCXXXVII of } 2013 \text { on Credit Institutions } \\
\text { and Financial Enterprises }\end{array}$ \\
\hline $\begin{array}{l}\text { EGAP/ } \\
\text { Czech Republic }\end{array}$ & 1992 & $100 \%$ state property ${ }^{1}$ & $\begin{array}{l}\text { Czech Export Bank, } \\
\text { Inc., UniCredit Bank Czech Republic } \\
\text { and Slovakia, Inc., Czech Savings Bank, } \\
\text { HSB Bank plc etc. }\end{array}$ & $\begin{array}{l}\text { OECD Consensus, Berne Union, } \\
\text { EU directives [20-22], Law on } \\
\text { Insurance and Export Financing with State } \\
\text { Support No. 58/1995 }\end{array}$ \\
\hline $\begin{array}{l}\text { ALTUM } \\
\text { Latvian Guarantee } \\
\text { Agency (LVA)/ } \\
\text { Latvia }\end{array}$ & $\begin{array}{l}2013- \\
2015\end{array}$ & $100 \%$ state property ${ }^{2}$ & $\begin{array}{l}\text { ZGI Capital, MTB, UniCredit, OP Bank, } \\
\text { PrivatBank, Norvik Banka, Danske } \\
\text { Bank, DNB, Nordea, Flycap, SwedBank, } \\
\text { SEB, LPB, Krediidipank, Industrial and } \\
\text { Commercial Bank of China }\end{array}$ & $\begin{array}{l}\text { OECD Consensus, EU directives [20-22], } \\
\text { Law on Financial Institution of } \\
\text { Development, Commercial Law, Rules of } \\
\text { the Cabinet of Ministers on the ALTUM } \\
\text { Advisory Board }\end{array}$ \\
\hline $\begin{array}{l}\text { Export Import Bank of } \\
\text { China / China }\end{array}$ & 1994 & $100 \%$ state property & $\begin{array}{l}\text { information about official partners is } \\
\text { unavailable }\end{array}$ & $\begin{array}{l}\text { Not guided by the principles of the OECD; } \\
\text { It is under the supervision of the China } \\
\text { Banking Regulatory Commission (CBRC). } \\
\text { Acts in accordance with the Law of the } \\
\text { People's Republic of China On Commercial } \\
\text { Banks No. } 47 \text { (May 10, 1995), the Law of } \\
\text { the People's Republic of China On } \\
\text { Regulation and Supervision of Banking } \\
\text { (December 27, 2003) }\end{array}$ \\
\hline $\begin{array}{l}\text { Chinese Export-Credit } \\
\text { Insurance Corporation } \\
\text { Sinosure / China }\end{array}$ & 2001 & state institution & $\begin{array}{l}\text { Bank of China, HSBC, Industrial and } \\
\text { Commercial Bank of China, Guangdong } \\
\text { Development Bank, Industrial Bank CO., } \\
\text { LTD, China-Africa Development Fund } \\
\text { Co., Ltd., China Merchants Bank, } \\
\text { Standard \& Chartered Bank, Russian } \\
\text { Gazprombank, China Agricultural } \\
\text { Development Bank, JPMorgan Chase } \\
\text { etc. }\end{array}$ & $\begin{array}{l}\text { Berne Union. It is under the supervision of } \\
\text { the The China Insurance Regulatory } \\
\text { Commission. } \\
\text { Acts in accordance with Article } 2 \text { of the } \\
\text { Insurance Law of the People's Republic of } \\
\text { China (June } 30,1995 \text { ) }\end{array}$ \\
\hline $\begin{array}{l}\text { The Export-Import Bank } \\
\text { of the Republic of China } \\
\text { / Taiwan }\end{array}$ & 1979 & $\begin{array}{l}\text { state financial } \\
\text { institution }\end{array}$ & $\begin{array}{l}\text { E. Sun Bank, First Bank, Bank SinoPac, } \\
\text { CTBC Bank, EBRD, Japan Trade } \\
\text { Insurance Agency (NEXI), the } \\
\text { Indonesian Export Insurance Agency } \\
\text { (ASEI), the Swedish Export Credit } \\
\text { Guarantee Commission etc. }\end{array}$ & $\begin{array}{l}\text { Berne Union. } \\
\text { Under the supervision of the Ministry of } \\
\text { Finance, the Financial Supervision } \\
\text { Commission }\end{array}$ \\
\hline Atradius / Netherlands & 1925 & private company $^{3}$ & $\begin{array}{l}\text { Active cooperation with national and } \\
\text { foreign financial institutions }\end{array}$ & OECD Consensus, EU directives [20-22] \\
\hline $\begin{array}{l}\text { EULER HERMES / } \\
\text { Germany }\end{array}$ & 1893 & $\begin{array}{l}\text { private insurance } \\
\text { company }^{4}\end{array}$ & $\begin{array}{l}\text { Al Hilal Takaful (Abu Dhabi), Arkéa } \\
\text { Banque Entreprises et Institutionnels } \\
\text { (France), Allied Irish Banks (Ireland), } \\
\text { Banco do Brazil (Brazil) and Unicredit } \\
\text { (Italy), HSBC US (Malaysia), Bpifrance, } \\
\text { BNP Paribas (France), ICIC (Israeli } \\
\text { Credit Insurance Company) etc. }\end{array}$ & OECD Consensus, EU directives [20-22] \\
\hline $\begin{array}{l}\text { Spanish Export Credit } \\
\text { Agency CESCE / Spain }\end{array}$ & 1970 & Mixed ownership ${ }^{5}$ & $\begin{array}{l}\text { Active cooperation with national and } \\
\text { foreign financial institutions }\end{array}$ & $\begin{array}{l}\text { OECD Consensus, EU directives [20-22], } \\
\text { Law } 8 / 2014 \text { of } 22 \text { April on State coverage } \\
\text { of Spanish internationalisation risks, Royal } \\
\text { Decree } 1006 / 2014\end{array}$ \\
\hline
\end{tabular}

Source: compiled by author based on [19, 23-32].

1 the Ministry of Finance (40\%), the Ministry of Industry and Trade (36\%), the Ministry of Foreign Affairs of the Czech Republic (12\%), the Ministry of Agriculture of the Czech Republic (12\%).

2 Ministry of Finance (40\%), Ministry of Economy (30\%), Ministry of Agriculture (30\%).

3 Grupo Catalana Occidente, S. A. (35.77\%), Grupo Compañía Espanõla de Crédito u Caución, S. L (64.23\% ).

4 most of the shares belong the French company Allianz France, acts as an agent of the government on the basis of the contract

5 Spanish government (50.25\%), Santander Group (23.88\%), BBVA Group (16.3\%), other banks (5.67\%), insurance companies (3.9\%). 
The study of the best international experience shows that ECA exists in several institutional forms and acts as quasigovernmental institutions or private institutions with government support. The similarity between ECA in different countries is due to the existence of common business practices and international principles and rules enshrined in the Consensus of the member-states of the Organization for Economic Cooperation and Development - a formal "OECD Recommendation on Common Approaches on Environment and Officially Supported Export Credits" of 2003 (the first regulatory instrument was the "Arrangement on Guidelines for Officially Supported Export Credits' (OECD Arrangement of 1978), - as well as the agreements of understanding of the Berne Union - the International Union of Credit \& Investment Insurers.

One of the basic principles embodied in the OECD Consensus implies the self-financing activities in the long term for ECA providing insurance of export credit risks with state support. The cooperation will be based on the agreement if ECA is a private company and works as an agent of the government. It should be noted that not all countries follow the above principles and use their own approaches to regulating the activities of export credit agencies.

The presented in comparative Table 1 information provides an opportunity to analyze foreign practice of export-credit agencies and show the active cooperation of ECAs with international financial institutions, regardless of their residence and ownership.

ECA significantly contributes to the expansion of their companies abroad, insuring investment risks, and some of them can invest and provide financial resources on favorable terms on commercial basis. It should be noted that, along with the traditional financing of investment contract insurance covering investment abroad and investment loan insurance abroad, the world's leading ECA actively investing from its own financial resources. The world's leading exportcredit agencies relying on their own investment rating are able to raise capital in domestic and foreign markets, directing it later in support of investment projects. These projects contribute to the implementation of the country's foreign economic policy and correspond to the basic concepts of the Sustainable Development implementing a long-term strategy for economic growth.

Export Development Canada (net income - 1.07 billion Canadian dollars in 2016) actively attracts financial resources on international capital markets to finance its programs. Due to AAA's highest investment rating, EDC attracted 10.4 billion of Canadian dollars at the end of 2016 on international capital markets by issuing debt financial instruments [33, p. 8, 39]. This allows the agency to act as one of the most powerful investors in Canada, supporting the entry of Canadian companies into foreign markets; investment decisions of EDC cover FDI, investments into international investment funds, and, of course, investment into Canadian investment funds. International investment promotes the active expansion of Canadian companies abroad and expands the export potential of the country. The agency actively provides direct loans to cover investment costs, in 2016 for these needs were provided 28 billion of Canadian dollars, which reflects the growth of $14 \%$ of Canadian investment support programs abroad. In general, in 2016 EDC made capital investments for 249 million of Canadian dollars [33, c. 22]. Canadian public and private companies gained support of investment operations through EDC financial instruments for 102 billion of Canadian dollars during this period [33, c. 4-5].

In the context of cooperation with international financial institutions, Hungarian Export Credit Insurance Ltd and Hungarian Export-Import Bank plc actively raise funds and create joint investment and trust funds such as the Trust Fund with IFC, Chinese Central and Eastern European Investment Fund with Export Import Bank of China. EXIM actively attract capital on domestic and international capital markets by issuing debt securities relying on its investment rating of BBB with stable outlook. In December 2012, Eximbank launched a program of medium-term notes with the support of underwriters Deutsche Bank and Jefferies International Limited, HSBC, J. P. Morgan and UniCredit Bank, which allowed the attraction of 2 billion euros at the London Stock Exchange. As a result of a successful bond issue, a stable and favourable structure of funds required for financial activity was provided with market resources in addition to state support needed to achieve strategic goals [24].

The total insurance coverage of Czech Export Credit Agency EGAP amounted 40.5 billion Czech korunas in 2015; 17 billion of the aforementioned sum was directed to insurance of investments abroad [34, p. 4, 9]. EGAP actively supports Czech investors who are going to invest in the construction of new production capacity abroad, including the purchase of existing production and obtaining of a share in the property of a foreign company etc ${ }^{6}$.

The process of the formation of the Latvian ECA ALTUM was finally completed in 2015, and lasted from 2013. During transformation period JSC "Latvian Development Finance Institution Altum" (until January 1, 2014 it was JSC "Mortgage and Land Bank of Latvia" founded in 1993), LLC "Latvian Gurantee Agency" (1998) and JSC "Rural Development Fund" (1994) were merged into one institution - JSC "Development Finance Institution Altum". The ALTUM support programs are implemented at the expense of public resources - such as funding attracted by the European Union, by other international institutions, by the state and directly by ALTUM. Under the development of investment programs ALTUM interacts with the European Fund for Strategic Investments (EFSI), such cooperation creates opportunities for Latvian entrepreneurs to finance and implement strategic projects with a high economic, environmental and social added value with the support of the

6 The investment should be a long-term investor's commitment for a minimum of 3 years. 
European Investment Bank. This cooperation allows attracting financing for investment projects in the amount of 50 million euros with the co-financing of the European Investment Bank. In 2017, Moody's assigned the investment rating Baal to the agency, which will allow the institution to rank among the issuers of bonds with the highest credit rating among the few bond issuers in the Baltic States. ALTUM plans to issue securities on stock exchanges in order to diversify the structure of financial resources and to ensure implementation of a number of state-supported investment projects in the Latvian economy. [25].

\subsection{Practical Recommendation for Implementation ECA in Ukraine}

In order to ensure ECA's effective work in Ukraine, it is important to recognize the difference in interest rates that can be offered by Ukrainian banks and foreign companies.

The difference among interest rates across countries leads to the fact that the company regardless of ownership find themselves at a disadvantage on the international arena. Since the cost of borrowing capital, for example in Germany (5.9\% in 2016) is lower in comparison with Ukraine (19.2\% for loans in UAH and 8-10\% for loans in euros in 2016); so it is easier and cheaper for German companies to obtain investment resources that can be invested in modernization and expansion of production capacities in comparison with Ukrainian ones $[35,36]$. The banking system of Ukraine is now experiencing not the best of times, so the cost of financing in Ukraine is higher compared to developed market economies. In this case, the feasibility of using Ukrainian Banks's financial products at high interest rates for foreign companies is irrelevant; but this is one of the important prerequisites for the functioning of the national ECA. There are several ways to solve this problem.

The first way is to attract financial resources of foreign banks. In this case, it is necessary to gain the support of international donors, which will foresee the signing of Memoranda of Cooperation with international partners on the foreign banks`s loans for financing of export and investment contracts of national companies. In order to interest the foreign bank in such cooperation, it is necessary to get the support of international donors who will act as guarantors for Ukrainian ECA. As a result of such cooperation, the foreign bank receives double guarantees - from the Ukrainian ECA and from the International Financial Institutions (IFIs). The guarantee support is needed during a certain transitional period, during which Ukraine will gain more confidence from foreign investors, and foreign financial institutions will finance long-term projects in Ukraine unreservedly, so subsequently, such a practice can be abandoned. In the context of ensuring the work of the proposed mechanism of stimulating ECA's development it is proposed that the Ministry of Finance of Ukraine initiate the issuance of guarantees of support of ECA 'S projects that will facilitate the cooperation with foreign financial institutions based on a memorandum of cooperation with IFIs.

The second option for Ukrainian ECA's support by international donors is to provide some compensation for interest rates, which will cover the existing difference in interest rates on the domestic and foreign markets, because Ukrainian interest rates are not attractive and appropriate for foreign partners. This mechanism will be extremely beneficial for the Ukrainian banking system - because it will increase the demand for banking products; also it will stimulate domestic production and development of export potential, as Ukrainian exporters gain a competitive advantage through financing programs at the same interest rates as it is offered by foreign banks. This mechanism involves the creation of special financial instruments to support the development of ECA in the transitive economies and developing countries. The relevant financial instruments will perform a compensatory function of equalizing longterm market interest rates for large projects. Taking into account the large size of the state-owned banking sector in Ukraine (as of February 2018, the share of state-owned banks in total assets of all solvent banks amounted to $54.9 \%$ ), it is reasonable to realize compensations for the interest rate differential through state banks, which will be final beneficiaries and receive compensation for the difference in interest rates, providing loans for export and guarantees for investment contracts at the rates operating in developed market economies [37].

In future it is expedient to consider the possibility of entering international capital markets by newly-created Ukrainian ECA in order to attract capital to finance long-term projects. The study showed that the relevant practice is widespread among foreign agencies. Cooperation with international donors can contribute to the success of this strategy in Ukraine. We propose to introduce special financial instrument - ECA's compensatory guarantees, which will provide financial intermediaries with compensation for the difference in the value of bonds if the bid price is higher than ask price. This mechanism will provide effective cooperation with the underwriters on bonds placement procedure issued by Ukrainian ECA under fully guaranteed underwriting. The relevant financial instrument will help reduce the coupon and increase the demand for financial assets. In order to implement the proposed mechanism, the Ministry of Finance of Ukraine, in conjunction with IFIs, such as the WB, EBRD, is called upon to develop a tool for the purpose of providing ECA with guarantees to enter the international capital markets. Relevant measures will facilitate the implementation of the Strategy for reforming the public finance management system for 2017-2020 in Ukraine in the context of broadening the investor base into government securities [38]. By no means taking into account the low rating of Ukraine in OECD risk classification, the best option would be to obtain guarantees from IFIs directly, but the alternative is the issue of guarantees by Ministry of Finance with the support of international donors. In order to prevent the negative impact of the growth of debt on bonds issued by ECA on the level of public debt, it is proposed to disregard the issued ECA's emission guarantees in the calculation of the value of the public debt determined in $60 \%$ of the actual 
annual GDP of Ukraine by Article 18 of the Budget Code [39]. For the maximum amount of guarantees provided, it is proposed to use a value equal to the GDP growth rate for the past year from the "ceiling" of $60 \%$, as determined by the Code. Appropriate measures will contribute to the implementation of the Strategy for Reforming the Public Finance Management System in the context of strengthening the defense mechanisms of the issue of state guarantees.

The system of company's selection for participation in the above proposed innovative programs of cooperation with IFIs through the ECA should be implemented during development of the final concept of ECA's activities in Ukraine. Trying to find answer what areas to provide with state support P. Krugman offers to choose the ones that contribute to the growth of the national economy, creating new and developing related industries. However, the scientist opposes government support to the sectors of "end products" as it leads to slower development and a waste of public resources [40].

Defining priority sectors and state-owned enterprises that will be subject to ECA's cooperation programs with the support of international donors, it is also necessary to take into account the potential fiscal risks posed by state-owned enterprises. Therefore, the selection of long-term projects in Ukraine should be based on the analysis of the report of the Ministry of Finance of Ukraine, as reflected in the budget declaration for 2019-2021, which contains an expanded assessment of fiscal risks in accordance with the IMF's Code of Fiscal Transparency. Accordingly, as a result of the analysis, it is proposed to develop a register of state-owned enterprises that will be subject to the program of cooperation with the ECA together with IMF, WB, EBRD and other IFIs as an element of improving the Strategy for Reforming the Public Finance Management. The register should be formed both on the basis of an analysis of potential opportunities for the creation of new and development of adjacent production industries as a result of the economic activity of the enterprise, and also taking into account its potential fiscal risks for the state budget. This measure will define the priorities in development of domestic production, and also select the sectors that are a priority for funding and development of investment programs supported by international donors. These measures will promote compliance with the plan of measures for implementation of the Strategy for Reforming the Public Finance Management System for 2017-2020, approved by the Cabinet of Ministers of Ukraine on May 24, 2017 [38]. Namely - the creation of the above register will facilitate the implementation of measures to improve the database of the public sector. Also, the selection of companies for ECA`s programs based on the developed register will facilitate the introduction of strategic planning of public investment and unification of approaches to the evaluation and selection of investment projects for financing as well as the development of effective centralized system for coordinating public investment management. In order to enhance the efficiency of ECA's activities, an effective mechanism for monitoring joint projects with IFIs should be introduced by the authority.

Inclusion in the report of the Ministry of Finance on the fiscal risks of a separate subdivision on the results of the activities of the enterprises which agreed program of cooperation with the ECA would allow receiving information about the reduction of fiscal risks in these enterprises promptly. Appropriate measures would facilitate rapid monitoring of the effectiveness of cooperation programs between ECA and IFIs; and would help to analyse and evaluate the impact of the Agency on public finance management system.

Taking into account the insufficient level of development of the insurance market in Ukraine, it is proposed to use the experience of countries that have created ECA on the basis of state-owned banks. However, effective work in this direction will be achieved through cooperation with both private and public institutions with the aim of diversifying the channels of capital inflows and thereby expanding investment opportunities by offering various financial instruments and programs of support. The best practice for attraction extra capital for ECA will be issuing securities on international capital markets. For newly created institutions, this mechanism requires significant support from the side of international donors. Therefore, in the initial stages, it is possible to work on the basis of signed protocols on cooperation with state and private banks.

\section{Conclusion}

The introduction of ECA in Ukraine relates to institutional factors contributing to the planning and implementation of reforms in the context of interaction with international donors and International Financial Institutions (IFIs); the supporting programs will be based on the signing of appropriate memoranda of cooperation. International technical assistance can help in solving problems associated with ECA`s project funding activities in Ukraine.

The proposed new financial instruments can promote the effective functioning of Export Credit Agency in Ukraine. These include the instrument of the targeted provision of guarantees to the national ECA for the entry into international capital markets - ECA's emission guarantees, which will boost demand for bonds issued by the Ukrainian ECA, which will increase the range of interested investors. Taking into account the uncompetitiveness of interest rates offered by Ukrainian financial institutions it is proposed to introduce financial instruments that will perform the compensatory function of equalizing market interest rates for long-term large projects. In order to attract foreign financial resources and foreign financial institutions to cooperation, it is proposed to release the issuance of ECA's development tools - guarantees of support of ECA'S projects on the Memorandums of Cooperation with the IFIs. A necessary step is to develop cooperation with the IMF, WB, EBRD and other IFIs in context of formation special register of SOEs which will be involved into the program of cooperation with the ECA on concessional terms. 
The study of the best world practices in the functioning of export-credit institutions allows us to draw conclusions about the importance of agencies' activities not only in stimulating the country's export potential, but also in attracting investment, forming an investment climate in the country, reducing information asymmetry, simplifying the processes of internationalization of enterprises, stimulating capital investment etc. ECA's advantage over other financial institutions is the ability to secure risks that cannot cover private lenders, which greatly enhances the expands funding opportunities for large projects. We analysed the institutional bases of stimulation of investment activity of enterprises belonging to the public sector, by creating an export-credit agency in Ukraine, emphasizing on the importance of ECA in creating conditions for attracting financial resources on favourable terms for state corporations which seek to purchase foreign expensive equipment, that do not have analogues on the domestic market.

\section{References}

[1] Export Finance Report (2016). TXF.

[2] The Law of Ukraine On Providing for Large-Scale Export Expansion of Goods (Works, Services) Originating in Ukraine through Insurance, Guarantees and Cheapening of Export Credits" № 1792-VIII. (2017). Vidomosti Verkhovnoi Rady Ukrainy, 4, 43.

[3] The Law of Ukraine "On the State Budget of Ukraine for 2018” № 2246-VIII (2018). Vidomosti Verkhovnoi Rady Ukrainy, 3-4, 26.

[4] Ukraine 2016 Article IV Consultation and third review under the extended arrangement. (Letter of intent and Memorandum on economic policy) (2017). IMF Country Report, 17/83.

[5] Stiglitz, J. (2008). Government Failure versus Market Failure: Principles of Regulation. IPD Working Paper, 144.

[6] Stiglitz, J. (1989). The Economic Role of the State. Basil Blackwell and Bank Insinger de Beaufort NV, 9-85.

[7] Krugman, P. (1981). Intraindustry specialization and the gains from trade. Journal of political Economy, 89 (5), 959-973.

[8] Krugman, P. (1979). Increasing returns, monopolistic competition, and international trade. Journal of International Economics, 9, 469-479.

[9] Krugman, P. (1981). Trade, accumulation, and uneven development. Journal of Development Economics, 8, 149-161.

[10] Krugman, P. (1991). Increasing Returns and Economic Geography. Journal of Political Economy, 99 (3), 483-499.

[11] Krugman, P. (1991). Geography and trade. Cambridge: The MIT Press.

[12] Krugman, P. (1996). The self-organizing economy. WileyBlackwell.

[13] Stiglitz, J., Weiss, E. (1981). Credit rationing in markets with imperfect information. The American Economic Review, 71 (3), 393-410.
[14] Mazzucato, M., Semieniuk, G. (2017). Public financing of innovation: new questions. Oxford Review of Economic Policy, 33 (1), 24-48.

[15] Goldzimer, A. (2002). Globalization's most perverse secret: the role of export credit and investment insurance agencies. Alternatives to Neoliberalism Conference. May 23-24, 2002.

[16] Ehlers, T. (2014). Understanding the challenges for infrastructure finance. BIS Working Papers, 454.

[17] Bhandari, R., Maurer, C. (2000). The climate of export credit agencies. World Resources Institute. Washington DC.

[18] OECD (2018). Country Risk Classifications of the Participants to the Arrangement on Officially Supported Export Credit. Organisation for Economic Co-operation and Development.

[19] Export Guarantee and Insurance Corporation (EGAP).

[20] Council Directive 98/29/EC of 7 May 1998 on harmonisation of the main provisions concerning export credit insurance for transactions with medium and longterm cover. (1998). Official Journal of the European Communities, L 148/22.

[21] Communication of the Commission to Member States amending the communication pursuant to Article 93(1) of the EC Treaty applying Articles 92 and 93 of the Treaty to shortterm export-credit insurance 2001/C 217/02. (2001). Official Journal of the European Communities, C. 217/44.

[22] Commission Notice on the application of Articles 87 and 88 of the EC Treaty to State aid in the form of guarantees. (2000). Official Journal of the European Communities, C 71/43.

[23] Export Development Canada. Retrieved from http://www.edc.ca.

[24] Hungarian Export Credit Insurance Ltd and Hungarian Export-Import Bank plc. Retrieved from https://exim.hu/

[25] Latvian Guarantee Agency (LVA). Retrieved from https://www.altum.lv/

[26] Export Import Bank of China. Retrieved from http://english.eximbank.gov.cn/en/

[27] The Export-Import Bank of the Republic of China. Retrieved from https://www.eximbank.com.tw/

[28] China Export and Credit Insurance Coporation (Sinosure). Retrieved from http://www.sinosure.com.cn/sinosure/english/English.html

[29] EULER HERMES. Retrieved from http://www.eulerhermes.com/

[30] Spanish Export Credit Agency CESCE. Retrieved from http://inglaterra.cesce.es/

[31] Bpifrance Assurance Export. Retrieved from http://www.bpifrance.fr/Qui-sommes-nous/Nosmetiers/International2/Assurance-Export.

[32] Atradius. Retrieved from https://group.atradius.com/

[33] Changing Trade (2016). EDC Annual Report. Retrieved from http://www.edc.ca/EN/About-Us/CorporateReports/Documents/annual-report-e-2016.pdf 
[34] EGAP Annual report 2015. Retrieved from http://www.egap.cz/dokumenty/vyrocni-zpravy/vyrocnizprava-2015-en.pdf.

[35] Statistical data. World Bank. Retrieved from https://data.worldbank.org/indicator/FR.INR.LEND?view=cha rt.

[36] Statistical data. IMF. Retrieved from http://data.imf.org/

[37] National Bank of Ukraine (2018). Overview of the banking sector (February 2018), 6.
[38] Order of the Cabinet of Ministers of Ukraine dated May 24, 2017 No. 415-p "On Approval of the Action Plan for Implementation of the Strategy for Reforming the Public Finance Management System for 2017-2020”. Cabinet of Ministers of Ukraine.

[39] The Law on the Budget Code of Ukraine (2010). Vidomosti Verkhovnoi Rady Ukrainy, 50-51, 572.

[40] Krugman. P. (2010). The new economic geography, now middle-aged. Regional Studies, 45 (1), 1-7. 